\title{
Once again: Investigating the identity of the three figures mentioned in Malachi 3:1
}

\author{
S D Snyman \\ (University of the Free State)
}

\begin{abstract}
Once again: Investigating the identity of the three figures mentioned in Malachi 3:1
\end{abstract}

The identity of the three figures mentioned in Malachi 3:1 remains an intriguing question for scholars. In this article an overview of the current state of research on this problem is given highlighting the strengths and weaknesses of the different solutions while yet another proposal is made adding some new arguments to existing answers. An overview on the history of research done on this problem can be categorised into three groups: the three figures refer to three different personalities or they all refer to the same person or they refer to two different persons. The conclusion reached is that the three figures mentioned are references to two persons, the one human and the

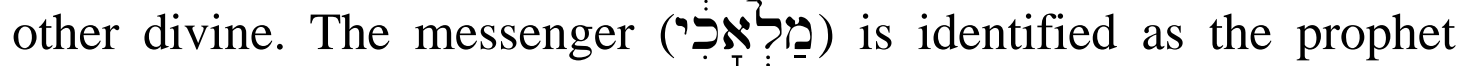
Malachi.

1 INTRODUCTION AND PROBLEM STATEMENT

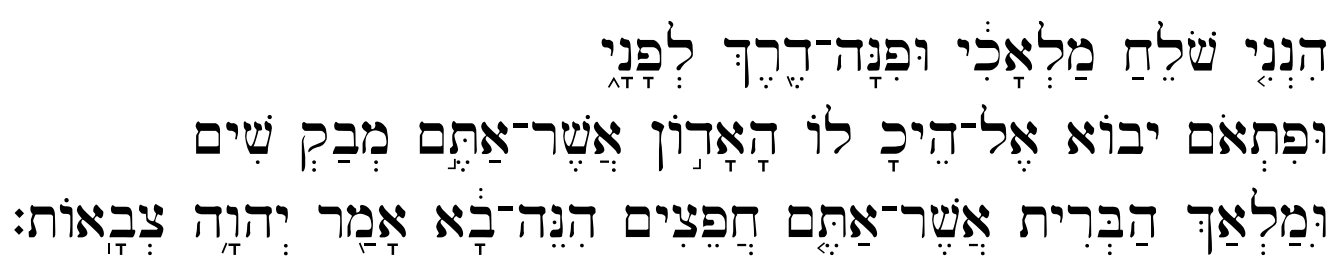

Three figures are mentioned in Malachi 3:1. In 3:1a "my messenger"

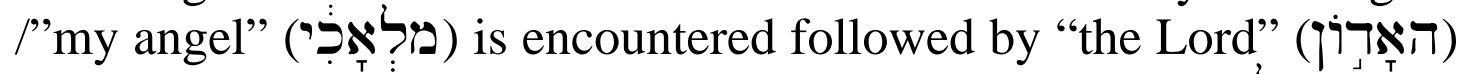
and a "messenger/angel of the covenant" (מלבאין הַברּרית). The identity of the three figures mentioned in Malachi 3:1 remains an intriguing question for scholars. Who are these figures? Do they refer to one, two or three persons and/or deities? The identification

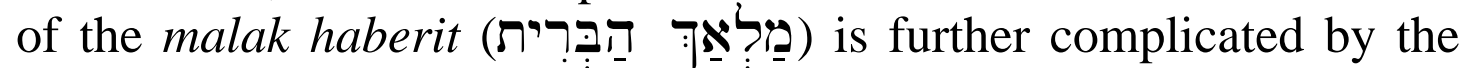
fact that there is no exact parallel to this figure in the rest of the Old Testament. In this article an overview of the current state of research on this problem is given highlighting the strengths and weaknesses of the different solutions while yet another proposal is made adding some new arguments to existing answers given to this problem. 
The answers given to this question are tied up with redactional issues, therefore attention must be paid to a redactional investigation before one can start investigating the identity of the three figures mentioned.

\section{REDACTIONAL ISSUES}

The interpretation and identification of the three figures mentioned is closely connected to redactional issues in this unit. Scholars noted that third person singular forms dominate in 3:1b-4 (he will come to his temple v1; his coming, he appears, he is like fire v2; he will sit, he will purify and refine v3) while 3:1a, 5 is characterised by first person singular forms (my messenger v1; I shall come near, I shall be v5). This observation led scholars to the conclusion that 3:1b-4 represents a later hand at work (Van der Woude 1981:290-293, Renker 1979:92, Deissler 1988:330, Koenen 1994:54; Petersen 1995:209-212). Originally, the unit consisted of 2:17-3:1a, 5 in which the question "Where is the God of justice?" (2:17) is clearly answered followed by "I will come near to you in justice" (3:5). Of course not all scholars are convinced that the whole of 3:1b-4 comes from a single redactor. Elliger (1975:205) ascribes 3:1c, 3-4 to a later hand and Koenen (1994:54-56) sees a more complex period of growth in the text. Lescow (1993:115) is convinced that 3:1a, 5 provides the answer to the question put in $2: 17$. 3:1b, 2 is a later addition, a kind of a sermon on the initial part ("Predigtzuwachs") and 3:3, 4 represents a further addition, a kind of a commentary on the text ("Kommentarzuwachs"). Furthermore it should be noted that verse 4 does not have any third person singular forms as in 3:1b-3. If one adhere to the theory that 3:1b-4 was added later, verse 4 presents one with a problem.

The approach adopted here is that only 3:1a should be seen as a later interpolation due to the first person singular forms used. Before the Lord himself will (suddenly) come, a redactor or later hand introduces someone else. The Lord will send his messenger on a preparatory mission to clear and prepare the way for his own coming.

3:1b ff may well be seen as an apt answer to the question posed by the people. On the question put in 2:17, a logical answer follows: the Lord (הָאדרין) will suddenly come to his temple (3:1b-2) according to the wishes and desire of the people (2:17) and there He will execute an investigation aimed at the Levites to restore proper 
worship and offerings (3:3-4). The book of Malachi is known for its emphasis on cultic matters $(1: 6-2: 9 ; 2: 10-16 ; 3: 8-10)$. It is therefore not strange or foreign to the book to have yet another unit emphasising cultic matters. The coming of the Lord entails a second dimension. He will also come to judge social and ethical malpractices (3:5). There is thus no need to question the God of justice for He has not changed (3:6a); it is in fact they, the people of God, whose conduct can be described as a turning away from the decrees by their constant disobedience (3:7a).

\section{HISTORY OF RESEARCH}

An overview on the history of research done on this problem can be categorised into three groups.

\subsection{The three figures refer to three different persons}

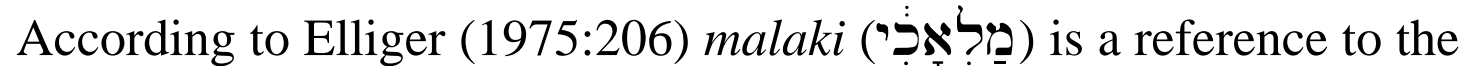
prophet who has the task of preparing the coming appearance of God. The ha'adon (הָאָדiן) is a reference to God coming to his

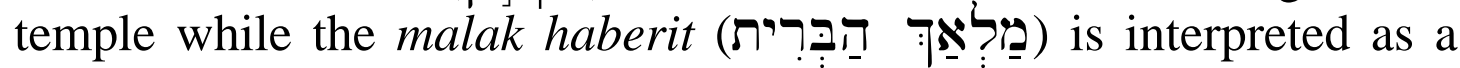
later addition to the text and identified as a guardian angel. Closely related to Elliger's results is the standpoint of Koenen (1994:54-59).

Malchow (1984:252-255) interprets the identities of the three figures as a prophetic figure based on Isa 40:3 referred to as malaki

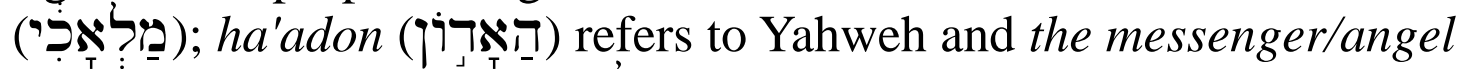

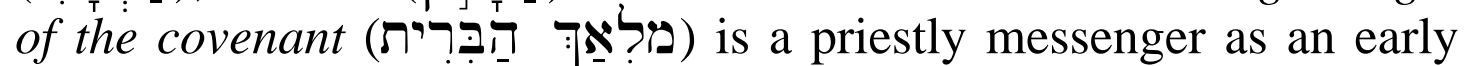
form of an awaited messianic figure from Levi. Baldwin (1978:242243) also identifies three different personalities. Although the identity of "my messenger" is not revealed, it is to be seen as someone with a unique mission as a (prophetic) forerunner distinguished from the messenger/angel of the covenant. The figure of ha'adon (הָדָרון) refers to the Lord, Yahweh, while the messenger

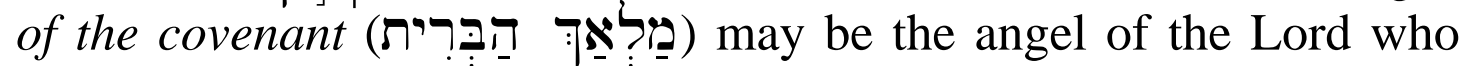
was instrumental in the establishment of the Mosaic covenant.

Summa summarum: there is scholarly consensus that the

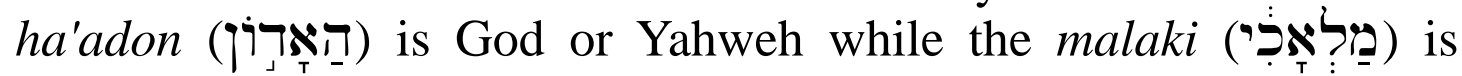
either the prophet Malachi (Elliger), an unnamed prophet (Malchow) or a prophetic forerunner (Baldwin), with the malak haberit (מלראַּד (הַבְרִית) either an angel (Elliger, Baldwin) or a priestly messenger (Malchow). 


\subsection{The three figures refer to one and the same person}

A second option is the exact opposite of the first one described above: instead of viewing the three figures as three different personalities, they should rather be seen as one and the same figure.

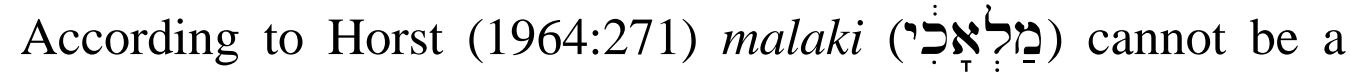
human figure one should rather think of "eine Abspaltung von Jahwes eigenem Wesen" acting as an organ and instrument of God (Horst 1964:271). Horst regards 3:1c as a later interpolation and does not give attention to the identity of the messenger of the covenant except to say that his task is apparently to restore the covenant of Levi referred to in Malachi 2:4ff. Horst comes thus close

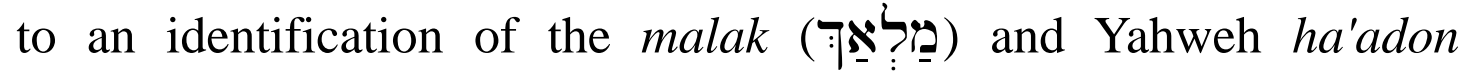
(הָאָדiּן). The most elaborate argument for identifying the three figures as one person comes from van der Woude (1981:289-300).

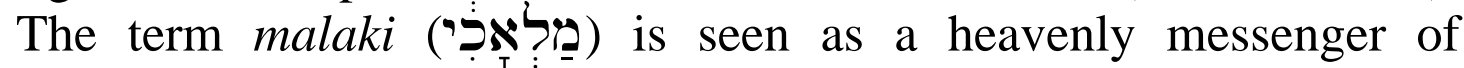
Yahweh, a vizier of God (van der Woude 1981:293; Van der Woude 1982:129). The term ha'adon (הָאדוֹן) cannot refer to Yahweh because when Yahweh has announced his coming and sent his angel to prepare the way for him, his coming cannot be seen as a sudden one. The parallelismus membrorum between v1b and v1c leads to

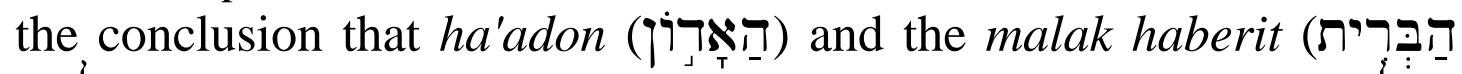

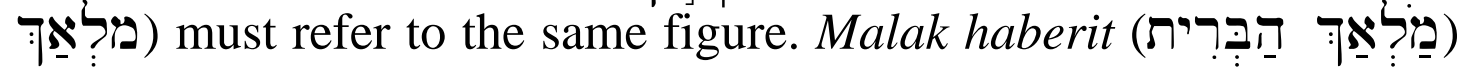
is likewise not a human messenger of Yahweh but a heavenly vizier

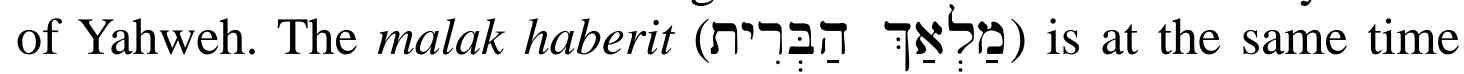
also lord of his temple. All this leads van der Woude to the conclusion that the three figures refer to one and the same person a heavenly vizier of Yahweh acting as the guardian angel of the covenant people of Israel (van der Woude 1981:298; van der Woude 1982:130). Van der Woude's interpretation is followed by Deissler (1988:330-331). Lescow (1993:119-120) sees the three figures as

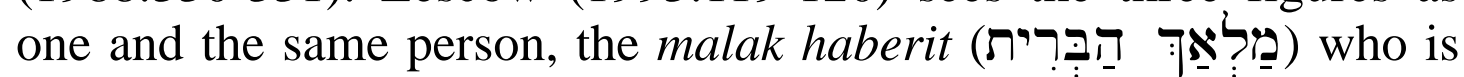
especially accountable for the temple and whose coming will serve to stabilise Yahweh's covenant with his people.

Summa summarum: the figures refer to Yahweh (Horst) or to a heavenly vizier of Yahweh (van der Woude, Deissler) or to the malak

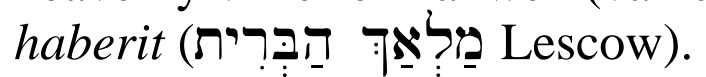

\subsection{The three figures refer to two different persons}

By far the majority of scholars are of the opinion that the three figures refer to two persons although not all agree on exactly which 
two persons are meant. Both Verhoef (1987:289) and Glazier-

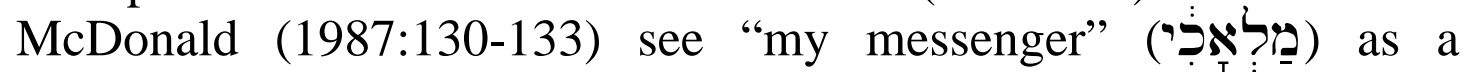
(human prophetic) forerunner messenger to the coming of the Lord (האדָדi). Due to the chiastic structure of the two sentences the "messenger/angel of the covenant" is associated with "the Lord" while at the same time "my messenger" is clearly distinguished from the other two titles. The relationship between the "Angel" and "the Lord" is thus the same as elsewhere in the Old Testament where "the angel of the Lord" is both identified with and distinguished from God (Verhoef 1987:289). Ridderbos (1935:219) came to the same conclusion: the malak (פַּלְ who is also called "the angel of the covenant". Two figures are distinguished: the prophetic forerunner called "my messenger" and God (referred to as "the Lord" and the "angel of the covenant").

Reventlow (1993:152) agrees with Verhoef and GlazierMcDonald that "the Lord" refers to Yahweh and that "the angel of the covenant" refers to "the Lord" due to the parallelism and the chiastic structure of the sentence: "der Engel des Bundes ...kann niemand anders als der 'Herr' im Parallelglied, also Jahwe selber sein”. Reventlow (1993:152) differs from Verhoef when he identifies "my messenger" with a heavenly representative of Yahweh. Reventlow follows the interpretation of Rudolph (1976:278-279)

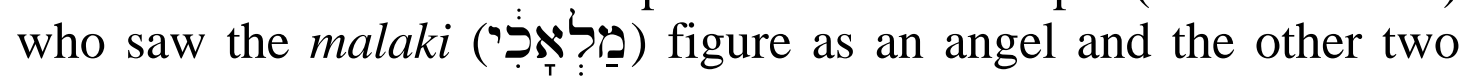
figures as Yahweh.

Several scholars identify ha'adon (הָאדָרון) and malak haberit

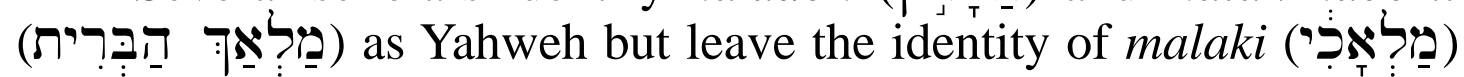
open. Smith (1980:62-63) is reluctant to identify the three figures. However, he comes close to the interpretation given by Verhoef by seeing "the Lord" as Yahweh and the "messenger of the covenant"

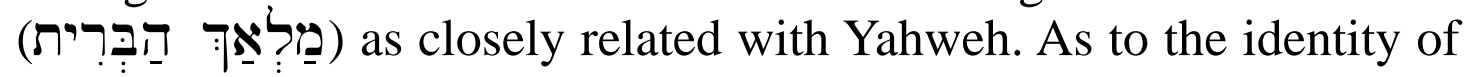
"my messenger", "No sure identification...is possible" (Smith 1980:63). Redditt (1995:176) holds that the reference to "the Lord" is Yahweh, that the angel of the covenant is the same as the angel of the Lord elsewhere in the Old Testament and that these two figures merged here as is often the case in the rest of the Old Testament. As to the identity of "my messenger" Redditt is of the opinion that it is "impossible to determine whether the prophet had himself or an angel of the Lord in mind". Achtemeier (1986:184) is convinced that the messenger of the covenant is identical with "the Lord" but the identity of the messenger preceding the coming of the Lord is not 
given. This is also the point of view Renker (1979:90-92) holds: the last two figures are references to Yahweh while the identity of "my messenger" must be left open. Smith (1984:327-328) is also reluctant to identify "my messenger" as we do not know whether he is a man or an angel. The ha'adon (הָאדרון) figure is identified as

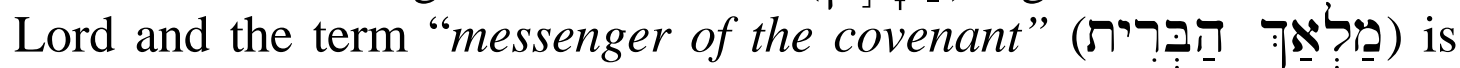
interpreted as "angel of Yahweh", a figure who represents Yahweh and is even sometimes interchangeable with him.

Weyde (2000:290) is convinced that ha'adon (הָדָדון) refers to Yahweh. The malak (פַלְֵַ) referred to in 3:1a "may suggest a priestly figure" who is later on identified closer as the messenger of the covenant (Weyde 2000:289-290). According to Krieg (1993:161, 162, 180, 226) ha'adon (האָדרן) refers to the Lord and the two

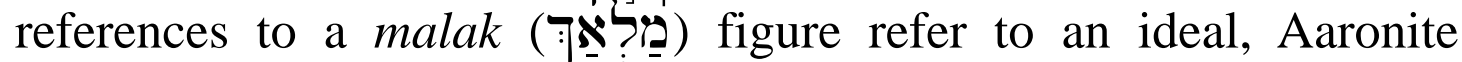
priest. Merrill (1994:429, 432) tentatively argues that since the word "malak" is used twice it must refer to the same (human) person with the task of preparing the way for the Lord. Enveloped between these two occurrences one finds ha'adon (הָדָדון) as a reference to Yahweh.

The point of view of Petersen (1995:210-212) is quite to the contrary. "My messenger" is a prophetic messenger while the other two titles due to the "strong elements of parallelism between the two lines" point in the direction of the same figure who might be a minor deity or a prophetic figure "endowed by the same sorts of powerful abilities that Elijah received according to Malachi 3:23-24”. The important and striking difference is that Petersen does not interpret

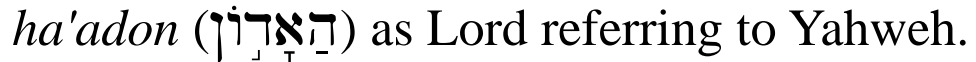

Although Deutsch (1987:100-101) stated that "the messenger's identity should not be in doubt at this stage”, he concentrated more on the task (preparing the way, salvation but not without judgement, trying to stop people doing evil) of the messenger than on his identity and thus leaves the reader without any clear indication of who the messenger is. As to the identity of the messenger of the covenant Deutsch is equally vague. On the one hand it seems that God is his own messenger but on the other hand it is also possible that Moses may be meant; in the end he concludes that "it is not very clear exactly what Malachi may have meant” (Deutsch 1987:101).

Some scholars opted for a messianic-Christological interpretation, distinguishing also two persons. The messenger (malaki 


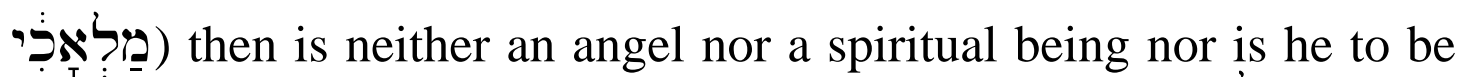

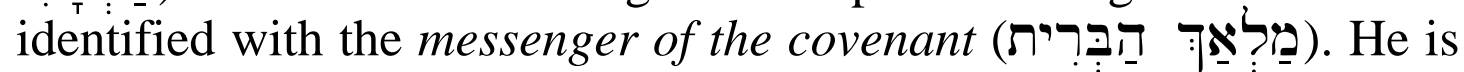
rather an earthly mortal, connected with the prophet Elijah who will announce the arrival of the second coming of the Messiah (Kaiser 1984:80). Kaiser (1984:81-82) also sees a close connection between ha'adon (הָאדין) as Yahweh and the messenger of the covenant

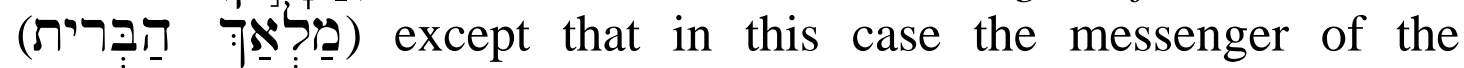
covenant is "to be identified with the preincarnate Christ". Stuart (1998:1350-1351) also is convinced that this verse is "unmistakably, overtly messianic". From this basic point of departure Stuart concludes that the messenger sent as a forerunner is John the Baptist and the Lord identified with the covenant messenger is Christ.

Summa summarum: Virtually all scholars in this category view

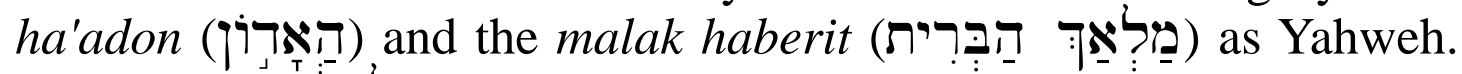

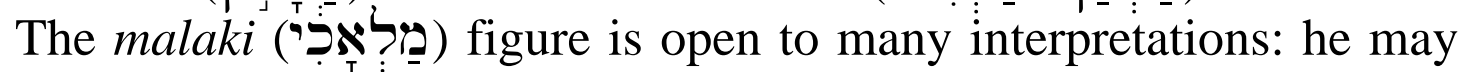
be a human (Merrill) prophetic forerunner (Verhoef, GlazierMcDonald, Ridderbos, Petersen) or a heavenly representative of Yahweh (Rudolph, Reventlow) or an ideal (aronite) priest (Krieg, Weyde). Many scholars chose not to identify the messenger (Smith, Redditt, Renker, Achtemeier). A few scholars opted for a messianicChristological interpretation (Kaiser, Stuart).

\section{RETHINKING THE IDENTITY OF THE THREE FIGURES IN MALACHI 3:1}

In this section new arguments to some of the solutions will be presented while other arguments will be criticised. From the previous section it is clear that there is almost consensus on the identity of the ha'adon (הָאדרון) figure and therefore this figure will

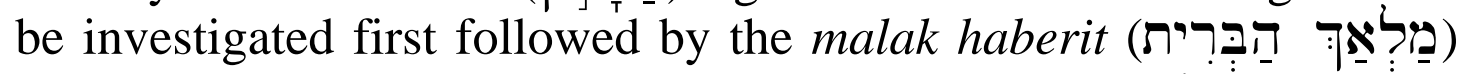

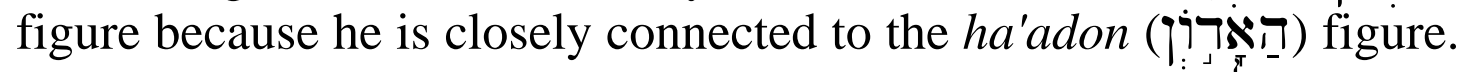

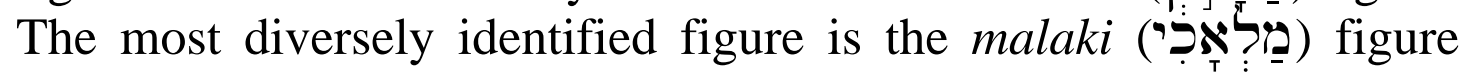
and therefore he will be treated last.

\subsection{The relationship between Malachi 1:6-2:9 and 2:17-3:7a}

When Malachi 1:6-2:9 and 2:17-3:7a ${ }^{1}$ are examined a surprisingly close connection between these two units is found. The noun ha'adon (האדָרון) occurs no less than four times in 1:6-2:9 and again

1 In a forthcoming paper the case for rendering Mal 2:17-3:7a as a pericope will be argued. 
in 3:1. Yahweh is not pleased with the priests $(1: 10)$ but is accused of being pleased with those who do evil (2:17) while they themselves desire the angel of the covenant to come (3:1). It is not only the priests who turned from the way (2:8); the people themselves also turned from the decrees of Yahweh (3:7). While it is wrong (ר) to bring blemished animals as an offering (1:8) Yahweh is accused of being pleased with all those who do evil (רע). The offerings mentioned frequently in $1: 6-2: 9(1: 10 ; 1: 11 ; 1: 13)$ are mentioned again in 3:3-4 where it will be offerings acceptable to Yahweh once again. In 1:11 it is foreseen that pure offerings will be brought and according to 3:3 the Lord will act as a purifier with the mission to purify the Levites. A true priest is seen as a messenger

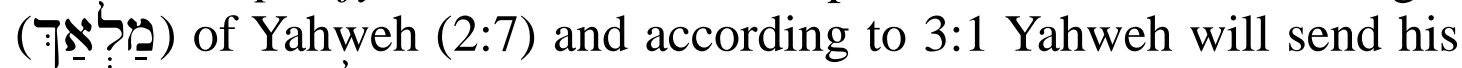

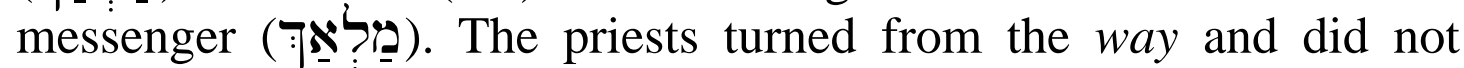
follow the ways of Yahweh (2:8-9) while in 3:1 Yahweh's messenger will come and prepare the way before him. In 1:6-2:9 the covenant (ברית) with Levi is mentioned $(2: 4,5,8)$ and in 3:1 the angel of the

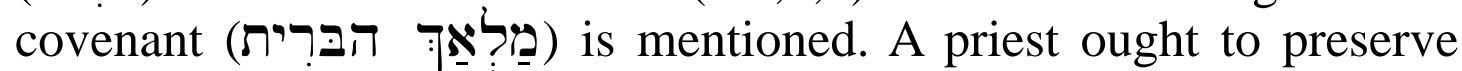
knowledge and follow the ways of Yahweh $(2: 7,9)$ while in 3:7 the people at large is accused of not keeping the decrees of Yahweh. Yahweh sent a curse (2:2) and his admonitions (2:4) but in 3:1 He will send his messenger. A true priest feared Yahweh (2:5) but the people did not fear Yahweh (3:5).

The similarities in vocabulary are too obvious to ignore so that there must be some connection between these two units. When these similarities are taken into account interesting wordplays (some more telling than others) are created between the two units. Yahweh is not pleased with the priests (1:10) according to the word of the prophet. According to the wearisome words of the people, Yahweh is pleased with those who do evil (2:17). It is not only the priests who turned away (2:8); the people as a whole turned away from Yahweh's decrees (3:7). The poor conditions of offerings brought (1:10-13) will be rectified (3:3-4). When a priest is no longer a worthy messenger of Yahweh (2:7), He will send his own messenger (3:1). This connection will serve as an aid in the interpretation of the disputed figures of Malachi 3:1.

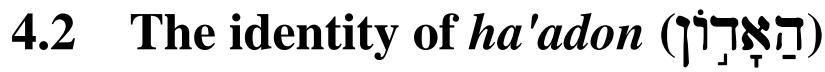

The overview of the history of research showed that virtually all scholars identify ha'adon (הָאדרון) with the Lord and consequently 
with Yahweh. It is significant to note that adon (אדוֹן É times in the book of Malachi (1:6 [twice]; $1: 12 ; 1: 14 ; 3: 1)$. It is noteworthy to mention that all of these occurrences are found in only one unit in the book, Malachi 1:6-2:9. In 1:6; $1: 12$ and 1:14 by adon (אדרוֹן) Yahweh or God is meant. In 1:6 a new unit is started with a proverb-like saying, "a son honours a father, and a slave his master" (adon אדון (אדון). The second half of the verse reveals that God is indeed an adon (אדוץ) He is the one to be feared and respected. Yahweh is seen as both a father and a master in this verse. In verse 12 one reads about the "table of the Lord". Verhoef (1987:232) is probably right that "Lord" is used here to emphasise the lordship of God over against the priests as human beings. What is interesting is that one encounters almost exactly the same phrase in 1:7 where one reads "table of Yahweh". Yahweh and the Lord are used as interchangeable terms to indicate the God of Israel in fact, it amounts to an identification of Yahweh and the Lord: Yahweh is the Lord and vice versa. Still within the same pericope, in 1:14 an offering is brought to the Lord (הָאדון). In verse 14 the term occurs in the context of a curse pronounced upon the people who dare to bring blemished animals as an offering to Yahweh. Yahweh is praised as a great king whose name is feared among the nations.

In 1:6, 1:12 and 1:14 Lord (הָאדרון) is used to indicate Yahweh. It would therefore be strange if that is not the case in 3:1. The reference to the coming of the Lord to his temple (היכָלוֹ) is another argument in this regard since it is only Yahweh who has the claim of having a temple (contra van der Woude).

In the rest of at least the prophetic literature adon (אָדוֹן) is mostly used to indicate Yahweh. Weyde (2000:290) remarks that ha'adon (הָאדרוֹן) with the definite article in all other biblical occurrences refer to Yahweh (Ex 23:17; 34:23; Isa 1:24; 3:1; 10:16; $10: 33 ; 19: 4)$. To a certain extent then it may be said that to identify ha'adon (הָאדרון) with Yahweh is to state the obvious. The use of

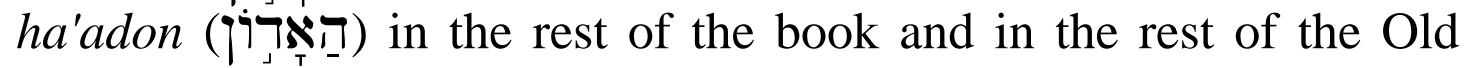
Testament is proof of this identification. Weyde (2000:291) also noted that the phrase "to seek the Lord" reminds one of a similar phrase ("to seek Yahweh") in other parts of the Old Testament. 


\subsection{The identity of the messenger/angel of the covenant (malak

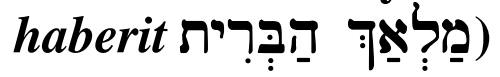

The problem of the identity of the messenger/angel of the covenant is complicated by the fact that this is the only place in the Old Testament where is phrase is found. As van der Woude (1981:292; van der Woude 1982:130) and others (Di Marco Angelico 1976:58; Verhoef 1987:288; Reventlow 1993:152) have pointed out, ha'adon

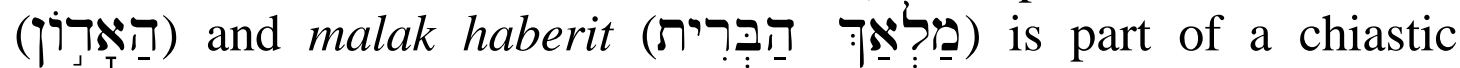
construction. The chiastic construction can be illustrated in a translation of the text:

Suddenly (A) he will come to his temple, (B) the Lord you are seeking

And (B1) the angel of the covenant/covenant angel in whom you delight.

Behold, (A1) he is coming, says Yahweh the Almighty.

Being part of a chiastic construction serves as an important indication in the quest for the identification of the malak haberit

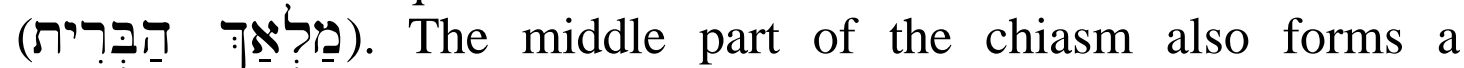
parallelismus membrorum (van der Woude 1981:294). These literary features of the text lead to the inevitable conclusion that ha'adon

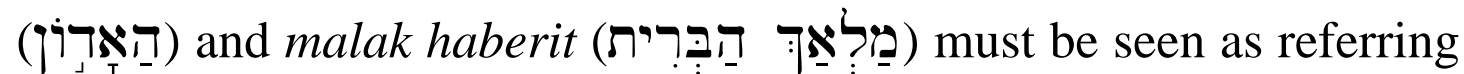
to the same person. At this very point however, scholars take

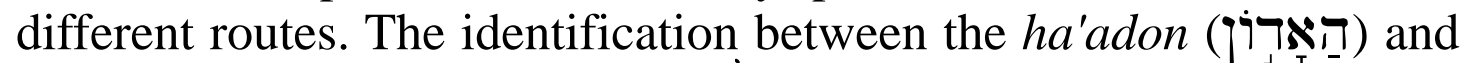

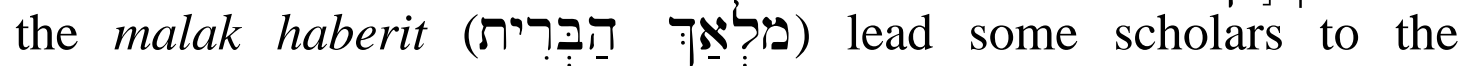
conclusion that these two figures do not refer to Yahweh at all (van der Woude 1981:294-295). Based on the argumentation above that ha'adon (הָאדרוך) must be a reference to Yahweh because of the use of the term in the rest of the book as well as in the rest of the Old Testament, van der Woude's conclusion can no longer be maintained.

The very same observation leads other scholars to exactly the

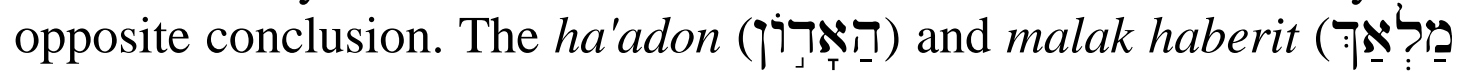
הַברִרית) are references to Yahweh in the second phrase Yahweh is presented as an angel as it is the case in other instances in the Old Testament where the angel of Yahweh comes very close to an identification with Yahweh himself. It is a case of distinguishing the angel from Yahweh while at the same time almost identifying the angel with Yahweh (Verhoef 1987:289). 


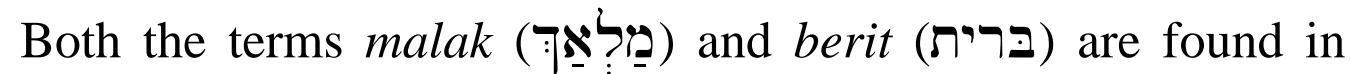
Malachi 1:6-2:9. In view of the close relationship between these two units the term berit (בּרית) most probably refers rather to the covenant with Levite priests rather than to the covenant at Sinai (so van der Woude 1981:297; Verhoef 1987:289). Weyde (2000:289)

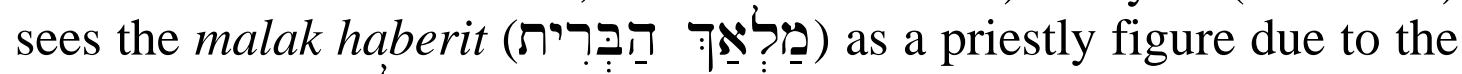

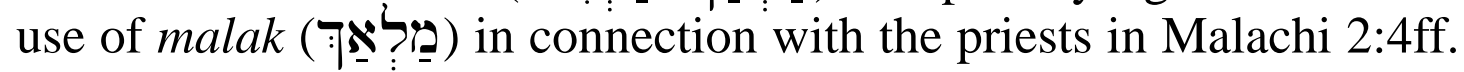
Contra Weyde I would argue in a different direction: while a priest ought to be a messenger of Yahweh preserving knowledge and giving instruction to the people, they failed to fulfil this function and therefore Yahweh himself will come as an angel of the covenant to restore proper worship and to judge those who do evil.

\subsection{The identity of the messenger referred to in Malachi 3:1a}

The introduction of a messenger of Yahweh, sent by Him on a preparatory mission before his own coming is found only in the book of Malachi and should therefore be regarded as a unique contribution to the eschatology of the Old Testament. Who is the messenger?

It is perhaps the safest option not to identify the messenger as some scholars do (Smith 1980:60-62; Redditt 1995:176; Renker 1979:90-92; Smith 1984:327-328; Achtemeier 1986:184). However, scholarly investigation will always try to find answers to questions not yet satisfactory answered. It is unlikely that a priestly messenger is envisaged as both Malchow (1984:252-255) and Krieg (1993:161$162,180)$ argued because of the devastating critique the prophet has on the priests and the curse that he eventually uttered upon the priests in 2:9.

The answer proposed here departs from the view that has been taken on the redactional history of the text. There it was argued that only 3:1a should be seen as a later addition to the text. The messenger of Yahweh is not a heavenly being or an angel, but is the prophet himself. Malachi, the prophet is the one performing the duties of preparing the way through his prophesies (so already Elliger 1975:208 but contra Van der Woude 1981:289; Reventlow 1993:152). That is also the reason why nothing else is said about him or the role he has to play it is all evident from his prophesies. His duty is to call the people to repent from their cultic and ethical malpractices before Yahweh will come to judge. There is thus an intended pun in the name of the prophet as he is both the messenger of Yahweh and at the same time Malachi, the prophet. So, the book 


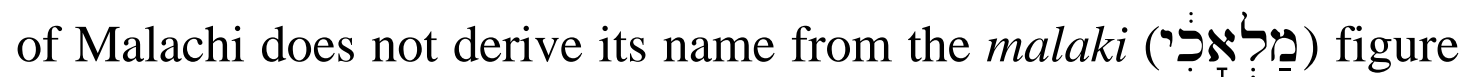
in 3:1a. It is also not "conceivable that Malachi would see himself or a coming prophet as one preparing the Lord's way" (Malchow 1984:252). It is rather the other way around. A prophet by the name of Malachi is identified by a later redactor as indeed the one who was sent on this mission to prepare the way for the Lord's coming in judgement.

The reason why a redactor put in this line, is perhaps because of the delay experienced in the execution of the promised judgement. According to the initial prophesy, Yahweh would come suddenly and as that had not happened yet, the reason for the delay must be explained. The reason given was that the prophet's coming had to be seen as a preparation for the actual coming of Yahweh. The time lapsed between the prophecy uttered and the actual coming of Yahweh is a time of preparation and repentance. Even later still, when the coming of Yahweh in judgment still did not materialise, it is foreseen that his coming will be preceded by yet another prophetic figure, the coming of Elijah (3:23).

The redactor probably got the idea of a messenger sent on a preparatory mission from an earlier source Isaiah 40:3 (Malchow 1984:252; Renker 1979:92). No indication is given as to whom the voice in Isa 40:3 belongs to. In Mal 3:1 the unspecified and vague voice crying out is somewhat more closely identified as Yahweh's messenger.

There is also the possibility that the idea of a messenger sent before Yahweh himself comes is found in Exodus 23:20 where Yahweh said that He is sending an angel ahead of the people to guard them along the way. It is however unlikely that this Exodusverse plays a role in the understanding of the messenger (contra Glazier-McDonald 1987:130). Firstly, these two texts address vastly different situations. In the one instance the people in the wilderness on their way from Egypt to the promised land and in the other instance the city of Jerusalem. In the Exodus text it is clearly the angel of Yahweh that is meant. In Exodus 23:21 it is said that "my name is in him" coming close to an identification of Yahweh and the angel. In the Malachi verse the messenger is not an angel but rather a human figure. As a text like 2 Chronicles 36:15f indicates, a malak (פַּלְאַ) may include figures like kings, prophets, priests, a Levite and civil leaders (Weyde 2000:288-289). 
The argumentation presented thus far makes it clear that it is doubtful whether a messianic-Christological interpretation of these figures can be maintained. While the idea of a messenger sent on a preparatory mission before the coming of the Lord is eschatological, it refers back to what already happened, namely when the prophet Malachi delivered his prophesies. There is no link to a future messianic figure, let alone a Christological reference. New Testament authors, however, viewed this text together with Isaiah 40:3 as a prophecy of the ministry of John the Baptist.

\section{CONCLUSION}

The three figures mentioned are references to two persons, the one

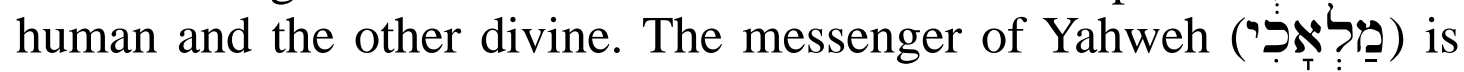
identified as indeed the prophet Malachi. A later redactor saw the prophesies of this prophet as the preparation for the coming of Yahweh himself. The coming of Yahweh in the form of his (covenant) angel would have the double aim of restoring proper worship as a correction to what the priests are unable to perform as well as acting as a judgement period to judge those who do evil. The initial question of the people on whether Yahweh is still the God of justice, is answered: Yahweh will come suddenly to his temple (3:1b) and He will approach the people in judgement (3:5). By doing that, Yahweh still remains the God of justice.

\section{Consulted literature}

Achtemeier, E 1986. Nahum - Malachi. Atlanta: John Knox (Interpretation).

Baldwin, J 1976. Haggai, Zechariah, Malachi, an Introduction and Commentary. Leicester: Intervarsity Press (TOTT).

Deissler, A 1988. Zwölf Propheten III. Zefanja Haggai Sacharja Maleachi. Echter Verlag (Neue Echter Bibel).

Deutsch, R R 1987. Malachi. Grand Rapids: Wm B Eerdmans (ITC).

Di Marco A, 1976. Der Chiasmus in der Bibel, 2.Teil. Linguistica Biblica 37, 49-68.

Elliger, K 1975. Das Buch der zwölf kleinen Propheten. Band II. Göttingen: Vandenhoeck \& Ruprecht. 7. durchgesehene Auflage (ATD 25).

Glazier-McDonald, B 1987. Malachi the Divine Messenger. Atlanta: Scholars. SBL Dissertation Series 98).

Horst, F 1964. Die zwölf kleinen Propheten. Nahum bis Maleachi. Tübingen: JCB Mohr (Paul Siebeck) (HAT 14).

Kaiser, W C Jr 1984. Malachi - God's unchanging love. Michigan: Baker Book House. 
Koenen, K 1994. Heil den Gerechte - Unheil den Sündern! Ein Beitrag zur Theologie der Prophetenbücher. Berlin: Walter de Gruyter (BZAW 229).

Krieg, M 1993. Mutmassungen über Maleachi. Eine Monographie. Zürich: Theologischer Verlag (AThANT 80).

Lescow, T 1993. Das Buch Maleachi. Texttheorie - Auslegung - Kanontheorie. Mit einem Exkurs über Jeremia 8,8-9. Stuttgart: Calwer (Arbeit zur Theologie 75).

Malchow, B V 1984. The Messenger of the Covenant in Malachi. JBL 103(2), 252-255.

Merrill, E H 1994. An Exegetical Commentary - Haggai, Zechariah, Malachi. Chicago: Moody Press.

Petersen, D L 1995. Zechariah 9-14 and Malachi. A Commentary. Louisville: Westminster John Knox (Old Testament Library).

Redditt, P L 1995. Haggai, Zechariah and Malachi. Grand Rapids: Wm B Eerdmans (NCBC).

Renker, A 1979. Die Tora bei Maleachi. Ein Beitrag zur Bedeutungsgeschichte von tora im Alten Testament. Freiburg: Herder.

Reventlow H G 1993. Die Propheten Haggai, Sacharja und Maleachi. Göttingen: Vandenhoeck \& Ruprecht (ATD 25/2).

Ridderbos, J 1935. De Kleinen Profeten. Opnieuw uit den grondtekst vertaald en verklaard. Derde deel: Haggai, Zacharia, Maleachi. Kampen: Kok.

Rudolph W 1976. Haggai - Sacharja 1-8 - Sacharja 9-14 - Maleachi. Gerd Mohn: Güterloher Verlagshaus.

Smith J M P 1980. A Critical and Exegetical Commentary on the Book of Malachi. Edinburgh: T \& T Clark.

Smith, R L 1984. Micah - Malachi. Waco, Texas:Word Books (WBC 32).

Stuart, D 1998. Malachi, in McComiskey, T E (ed) The Minor Prophets. An Exegetical and Expository Commentary. Vol 3. Michigan: Baker Books.

Van der Woude, A S 1981. Der Engel des Bundes. Bemerkungen zu Maleachi 3,1c und seinem Kontext, in Jeremias, J \& Perlitt L (eds) Die Botschaft und die Boten, Festschrift für Hans Walter Wolff zum 70. Geburtstag. Neukirchener: Neukirchen, 289-300.

-, 1982. Haggai Maleachi. Nijkerk: Callenbach (POT).

Verhoef, P A 1987. The Books of Haggai and Malachi. Michigan: Wm B Eerdmans (NICOT).

Weyde, K W 2000. Prophecy and Teaching. Prophetic authority, Form problems, and the use of traditions in the Book of Malachi. Berlin: Walter de Gruyter (BZAW 288). 